\title{
REPORT OF THE SUB-COMMITTEE ON FARM WOODLOTS
}

$\mathrm{T}$

HERE has been a marked advance in the interest taken in farm woodlots in the Eastern provinces this past year. All the farm papers have had articles on the woodlot. The city dailies and the local weeklies welcome articles and news items on the value and management of farm woodlots.

\section{PRINCE EDWARD ISLAND}

The Provincial Government sponsored a class of thirty young farmers in a month's training on woodlot management. The instruction was given at the Acadia Forest Experiment Station.

NOVA SCOTIA

The Department of Agriculture has appointed a forester to assist woodlot owners in marketing the products from farm woodlots.

\section{ONTARIO}

There has been a very intense interest and concern shown in the conservation of woodland in Southern Ontario this past year. This interest is the result of several factors.

1. Disastrous floods on several rivers in Southern Ontario has brought up the subject of causes and measures that should be taken to prevent floods. Many believe that the floods would not be so disastrous and many would not take place if a larger percentage of the watersheds was in woodland. There are, of course, thousands of acres of sub-marginal argricultural soils that should have been left in woodland and many swamp areas that should never have been drained.

2. Many farm wells and springs that always had water are dry part of the year. The cause of this shortage is the destruction of the natural reservoirs.

3. There is an increasing shortage of fuelwood and timber in many of the farming sections.

4. Many public-spirited men and newspaper editors have been talking and writing Conservation for many years and the interest shown to-day is largely the result of this. The government nursery at St. Williams, Ont., which has been carrying on reforestation and woodland improvement work for over 30 years, has also had a great influence in this work.

The movement was given direction by regional conferences that were 
called together by Mr. Porter, editor of "The Farmers' Advocate." Following these conferences, most of the county councils appointed conservation committees. These committees have been active in educational work and starting county forests.

\section{DEMONSTRATION WOODLOTS}

There are now 260 demonstration woodlots supervised by The Ontario Forestry Branch in the Province. Most of the woodlots are privately owned and are adjacent to, or within 40 rods of, a travelled road. The purpose of designating woodlots as demonstrations is to draw attention to woodlots that are being preserved and that have forestry principles applied to their management. Many of them are in fine condition following many years of wise and careful management. Others are being built up and improved by fencing from livestock, planting, thinnings and improvement cuttings. The farmer does the work at his convenience. Signs which state that it is a demonstration woodlot, the year that it was fenced from livestock, the year thinnings or improvement cuttings were done, are placed where they will be seen by passing motorists.

\section{KING TOWNSHIP SURVEY}

Mr. Aubrey Davis of Newmarket had a very intensive survey made of King Township this past summer. The survey was in charge of $\mathrm{Mr}$. Kenneth Mayall a Forestry graduate of the University of Toronto. There is now $5 \%$ of the township area in ungrazed woodland and $5 \%$ in grazed woodland. The objective is to restore the grazed woodland to fine, healthy woodland by fencing from livestock and in addition, to plant an extra $5 \%$. This will bring the area of woodland up to $15 \%$. It is hoped to rehabilitate the township in order that springs and streams that are dry part of the year will run continuously, that floods will be prevented, that there will be an adequate supply of water in farm wells, that erosion of clay banks will be stopped and that wild life and fish will be restored to the area. If carried out it will be an example that will have far-reaching effects. 